\title{
PROTEIN-LIPID RELATIONSHIPS IN HUMAN PLASMA: IN BILIARY CIRRHOSIS, OBSTRUCTIVE JAUNDICE, AND ACUTE HEPATITIS ${ }^{1}$
}

\author{
By HOWARD A. EDER, ${ }^{2}$ ELLA M. RUSS, R. A. REES PRITCHETT, MARY M. \\ WILBER, AND DAVID P. BARR \\ (From the Department of Medicine, The New York Hospital-Cornell Medical Center, \\ New York, N. Y.)
}

(Submitted for publication July 26, 1954 ; accepted March 16, 1955)

In 1862, Austin Flint (1) found that cholesterol accumulated in the blood in obstructive jaundice. Fifty years later Widal, Weill, and Laudat (2) pointed out that the hypercholesterolemia of obstructive jaundice is due in large measure to increase in serum free cholesterol in contradistinction to that of nephrosis, where both free and esterified cholesterol are greater than normal. More recently (3-5) it has been shown that plasma phospholipid increases even more than cholesterol, so that the ratio of total cholesterol to phospholipid is appreciably less than normal.

The serum lipoproteins have also been measured in patients with liver disease. Pierce and Gofman (6) examined the sera of thirty-two patients with cirrhosis and found levels of the $S_{f}$ 10-20 class slightly higher than normal. They also studied forty-eight cases of acute hepatitis (7) and found elevations of the $S_{t} 0-100$ components with the largest increase in the $S_{f} 12-20$ class. The increased concentrations correlated most closely with the presence of jaundice and tended to decrease when the jaundice subsided. McGinley, Jones, and Gofman (8) found a huge increase in the $S_{f} 6$ and $S_{t} 8$ groups, with varying increase in $\mathrm{S}_{\mathrm{f}}$ 10-17 in five cases of biliary cirrhosis. By starch zone electrophoresis, Kunkel and Slater (9) observed that in biliary cirrhosis there was a high peak consisting predominantly of phospholipid which had the same relative mobility as normal beta lipoproteins. The concentration of alpha lipoproteins was extremely low. Snavely, Goldwater, Randolph, and Unglaub (10) by ultracentrifugation of whole serum from pa-

1 These studies have been aided by a grant from the U. S. Public Health Service, by support from the Commonwealth Fund and the Albert and Mary Lasker Foundation, and by gifts from Mrs. Katherine Lilly Conroy.

2 Present address: State University of New York, College of Medicine at New York City, Brooklyn, N. Y. tients with acute hepatitis found an increase in light aggregates rich in neutral fat and poor in ester cholesterol.

In this present study, plasma proteins in patients with liver diseases in which biliary obstruction is a prominent or suspected feature were fractionated by Cohn's method number 10 and the fractions analyzed for protein and lipid constituents. In some of the patients, and especially in those with acute hepatitis, it was possible to analyze the plasma serially during the disappearance of jaundice and during the various phases of recovery from the disease.

\section{SUBJECTS}

The cases studied were classified as follows.

$\begin{array}{lr}\text { Biliary cirrhosis } & \text { Number of cases } \\ \text { Primary } & 7 \\ \text { Secondary } & 5 \\ \text { Bile duct obstruction } & 12 \\ \text { Acute hepatitis } & 30 \\ \text { Portal cirrhosis } & 36\end{array}$

The diagnosis of primary biliary cirrhosis was made on the basis of the clinical picture. In six of the seven patients (Table IIA), exploratory laparotomy revealed an appearance of the liver indicating biliary cirrhosis. There was no evidence of extrahepatic biliary obstruction. In one patient (Yaz), laparotomy was not performed, but needle biopsy of the liver yielded a specimen regarded as histologically typical of biliary cirrhosis. The duration of illness varied from six months in Pey and Ros, to eight years in Whe and Dor. In Pey, xanthomata were not present (perhaps because of the short duration of the disease). All of the other patients had xanthelasma, and with the exception of Whe had developed xanthomata in other areas. All of the patients had large livers and spleens. All of them were intensely jaundiced and had high concentrations of alkaline phosphatase at the time of plasma fractionation.

The diagnosis of secondary biliary cirrhosis was made in five patients with chronic jaundice in whom laparotomy 
and biopsy of the liver presented a picture compatible with biliary cirrhosis but in whom there was also evidence of extrahepatic biliary obstruction (Table IIB). In Kur and Fit the common bile duct had been damaged by previous surgery. Sto had a large congenital pancreatic cyst. Although no common duct stone was found in Drm and Bro, they were classified as secondary biliary cirrhosis because of chronic cholecystitis and the presence of stones in the gall-bladder. Duration of symptoms was from one and one-quarter years in Drm to eleven years in Fit and Sto. Drm, Fit, and Bro had xanthelasma but no evidence of xanthomatosis elsewhere. The others displayed no cutaneous lipid deposits. Two of the five patients (Drm and Fit) were not intensely jaundiced at the time of fractionation. All had serum alkaline phosphatase concentrations greater than thirty Bodansky units.

The group designated as bile duct obstruction (Table III) consisted of six patients with carcinoma of the pancreas, three with common duct stone, two with metastatic carcinoma of the liver, and one who had both hemachromatosis and primary liver cell carcinoma. The duration of jaundice varied from one to five weeks. All patients were jaundiced at the time that they were studied; in Kau and Smi subsequent studies were made following the relief of obstruction. In these patients, serum alkaline phosphatase concentration was elevated, and in Kau and Smi decreased along with serum bilirubin concentration.

Patients with acute hepatitis (Table IV) were not differentiated as to etiology. Eight of the thirty had histories of blood transfusions; none of them had a history of exposure to toxic substances. For convenience, the date of onset of the disease was arbitrarily defined as the day on which jaundice or dark urine was first recognized. Since, however, many of the patients had suffered vague symptoms for some days preceding the icterus, it was impossible to determine the duration of the illness with accuracy. It was thought that, in eleven, studies were initiated during the first week; in five, during the second; in twelve, during the third and fourth; and in two, still later in the course of the illness. Those observed during the first week after onset probably represent a random sample of cases of hepatitis admitted to the hospital during the period. Those in whom observations were initiated at a later time usually had persistent icterus. All of the patients with jaundice had also elevated levels of serum alkaline phosphatase and abnormal cephalin flocculation and thymol turbidity. These abnormalities disappeared as the concentration of bilirubin decreased. Bat and Dre died within a week of onset, and autopsies showed acute massive necrosis of the liver. Saz and Ols had less fulminating courses and died after day 23 and 83, respectively. All the other patients recovered.

The group of patients with portal cirrhosis (Table V) included thirty with progressive hepatic insufficiency, peripheral edema, and ascites. All but three of them offered histories of large alcohol intake. The group also included one patient with hemochromatosis and five young women who gave no history of alcoholism but who suffered from acne, amenorrhea, recurrent attacks of fever, jaundice, and other features of the syndrome described by Bongiovanni and Eisenmenger (11). Several of the patients with alcoholic cirrhosis had episodes suggestive of superimposed obstructive jaundice with marked elevation of serum bilirubin and clay-colored stools. This was apparent in Rob on 2/20/52 and in Guz on 9/16/53. Sko had a hemolytic anemia with high indirect bilirubin and greater than normal excretion of urobilinogen in the stool.

\section{METHODS}

Cohn's method number 10 was used for the chemical fractionation of the plasma proteins. Three fractions were isolated: IV $+\mathrm{V}+\mathrm{VI}$, II, and I + III. Plasma and all fractions were analyzed for protein and for cholesterol by the Bloor method. In some of the cases free and total cholesterol, phospholipid, and total lipid carbon were determined in unfractionated plasma and in Fractions IV $+V+V I$ and I + III. Details of the procedure of the fractionation of proteins and of the analytic methods have been previously described (12). Free and total cholesterol were determined by the method of Sperry and Schoenheimer as modified by Sperry and Webb (13). With very dilute samples it was necessary to concentrate the extracts by evaporation of solvent.

Paper electrophoresis was carried out by the method described in detail in a previous publication (14).

Ultracentrifugation was carried out in a Spinco model $\mathrm{L}$ preparative ultracentrifuge. The solvent density of the serum was raised to 1.063 by adding to $4 \mathrm{ml}$. of serum 4 ml. of $\mathrm{NaCl}$ solution containing $181.7 \mathrm{gm}$. per liter (15). Tubes were inverted and then centrifuged at 80,000 times gravity for thirteen hours at 15 to $16^{\circ} \mathrm{C}$. The top layer was removed, using a hypodermic syringe and curved needle. The top and bottom layers were analyzed for lipid and subjected to electrophoresis on paper.

\section{RESULTS}

In Tables II to $\mathrm{V}$ the results of cholesterol and phospholipid analyses of plasma and of the protein fractions have been assembled together with values for total serum bilirubin and the ratios of free to total cholesterol on the plasma. Observations on the Sperry-Schoenheimer (13) determinations and the free to total ratios of the fractions are presented separately in Table VI.

In order to facilitate comparison, normal values and ranges for two age groups have been listed in Table 1. For cholesterol by the Sperry-Schoenheimer method, normal values are available only for the younger group. In the older age group the values would probably be altered in a direction similar to that of the cholesterol values by the Bloor method (12). 
Normal values of concentration and distribution of protein, cholesterol, and phospholipids in plasma and fractions of normal young men and women

\begin{tabular}{|c|c|c|}
\hline & $\begin{array}{l}\text { Young men } \\
\text { and womenen } \\
\text { aged 18-35 }\end{array}$ & $\begin{array}{l}\text { Older men } \\
\text { and women } \\
\text { aged 45-65 }\end{array}$ \\
\hline \multicolumn{3}{|l|}{ Cholesterol (Bloor) } \\
\hline Plasma (mg. per $100 \mathrm{ml}$.) & 199 & 261 \\
\hline Fraction IV+V+VI (mg. per $100 \mathrm{ml})$. & $\begin{array}{c}(126-276) \\
58\end{array}$ & $\begin{array}{c}(171-354) \\
54\end{array}$ \\
\hline Fraction I+III (mg. per $100 \mathrm{ml}$.) & $\begin{array}{l}(39-93) \\
134\end{array}$ & $\begin{array}{c}(32-80) \\
187\end{array}$ \\
\hline \multirow{2}{*}{\multicolumn{3}{|c|}{ Phospholipid }} \\
\hline & & \\
\hline Plasma (mg. per $100 \mathrm{ml}$. ) & $\begin{array}{c}228 \\
(148-287)\end{array}$ & $\begin{array}{c}270 \\
(202-327)\end{array}$ \\
\hline Fraction IV+V+VI (mg. per $100 \mathrm{ml}$.) & 113 & 102 \\
\hline Fraction I+III (mg. per $100 \mathrm{ml}$. ) & $\begin{array}{l}(73-104) \\
106\end{array}$ & $\begin{array}{l}(75-140) \\
155\end{array}$ \\
\hline \multicolumn{3}{|l|}{ Cholesterol-phospholipid ratio } \\
\hline Plasma & 0.87 & 1.00 \\
\hline Fraction IV +V+VI & $\begin{array}{c}0.62-1.20) \\
0.51\end{array}$ & $(0.79-1.18)$ \\
\hline Fraction iv $+v+v i$ & $(0.32-0.64)$ & $(0.35-0.61)$ \\
\hline Fraction I+III & 1.26 & 1.38 \\
\hline \multicolumn{3}{|l|}{ Ester cholesterol (Sperry-Schoenheimer) } \\
\hline Plasma (mg. per $100 \mathrm{ml}$.) & 123 & \\
\hline Fraction IV+V+VI (mg. per $100 \mathrm{ml}$.) & 33 & \\
\hline Fraction I+III (mg. per 100 ml.) & $\begin{array}{c}(21-51) \\
81\end{array}$ & \\
\hline \multicolumn{3}{|l|}{ Free cholesterol } \\
\hline Plasma (mg. per $100 \mathrm{ml}$. ) & 49 & \\
\hline Fraction IV+V+VI (mg. per $100 \mathrm{ml}$.) & $\begin{array}{c}(42-64) \\
11\end{array}$ & \\
\hline Emin I & $(7-15)$ & \\
\hline Fraction I+III (mg. per $100 \mathrm{ml}$. ) & $\begin{array}{c}39 \\
(27-50)\end{array}$ & \\
\hline \multicolumn{3}{|l|}{ Free/Total cholesterol } \\
\hline Plasma & 0.29 & \\
\hline Fraction IV+V+VI & $\begin{array}{c}(0.22-0.35) \\
0.24\end{array}$ & \\
\hline Fraction I+III & $\begin{array}{l}(0.20-0.28) \\
0.33\end{array}$ & \\
\hline
\end{tabular}

\section{Primary biliary cirrhosis}

In Table IIA the results obtained in the eight cases of primary biliary cirrhosis have been assembled. Because the studies were made at various stages of the disease, each case is considered individually and averages are not determined. In the Table, the cases are arranged in the order of decreasing cholesterol concentration. In every case of the group the total cholesterol is greater than normal, although it tends to diminish in those of longer duration. The increased cholesterol tends to accumulate chiefly in Fraction IV $+\mathrm{V}+$ VI where in three of the cases it constitutes 70 per cent or more of the total concentration. In all of the patients, the phospholipids of the plasma increased more than the cholesterol with resultant marked lowering of the cholesterol-phospholipid ratios. This is almost entirely attributable to a disproportionate accumulation of phospholipids in Fraction I + III where the cholesterol-phospholipid ratios are grossly lower than normal and frequently approximate those of Fraction IV $+\mathrm{V}+$ 
VI where phospholipids increased proportionately to the cholesterol and where the cholesterol-phospholipid ratios deviated little from the normal average of approximately 0.5 .

Analysis of the plasma by the Sperry-Schoenheimer method shows that the increment in plasma cholesterol in all of the patients is due to accumulation of free cholesterol with a resultant increase in the ratio of free to total cholesterol. Even in Dor, however, where there is no increase in total plasma cholesterol, the free to total ratio is also markedly elevated. Analysis of several of the fractions (see Table VI) indicates that almost all of the cholesterol in Fraction IV $+\mathrm{V}+\mathrm{VI}$ is free, while Fraction I + III contains essentially all of the plasma esterified cholesterol in addition to free cholesterol.

In Table IIB are the data from the five cases of secondary biliary cirrhosis. The concentration of plasma cholesterol exceeds the limits of normal but is increased less than in the cases of primary biliary cirrhosis. With progressive hepatic failure the concentration tends to fall. The pattern of distribution of cholesterol is similar to that in primary biliary cirrhosis. In all patients, concentration of bilirubin is markedly elevated, the cholesterol-phospholipid ratios are considerably reduced, and the free to total cholesterol ratio markedly increased both in the plasma and in Fraction I + III. In Sto, as the jaundice increases the cholesterol-phospholipid ratios in plasma and Fraction I + III decrease, and the ratio of free to total cholesterol rises (see Table VI).

\section{Bile duct obstruction}

In Table III, the data on the patients with bile duct obstruction have been assembled. Patients were selected on the basis of considerable constant or increasing jaundice. Cases in which jaundice was decreasing were not included, although in two of the cases (Kau and Smi) measurements made after jaundice had begun to subside are included. In four of the patients, cholesterol in the plasma as well as in the two lipid-containing fractions is elevated. All of the patients in this group have low cholesterol-phospholipid ratios in the plasma and in Fraction I + III. In nine of the twelve cases in which cholesterol-phospholipid ratios and free to total cholesterol ratios are extremely abnormal, history indicates that the obstruction has been of less than six weeks' duration. These patients with bile duct obstruction of relatively short duration and presumably normal livers demonstrate most clearly the effects of obstructive jaundice on plasma cholesterol-phospholipid ratios and free to total ratios. Restoration of normal lipid interrelationships after relief of obstruction is indicated in Smi.

\section{Acute hepatitis}

In Table IV, the data on the thirty cases of acute hepatitis have been assembled. The patients are listed in order of time elapsed between the onset (the day when jaundice or bilirubinemia was first noted) and the first analysis of the plasma.

The deviations in lipid concentration and distribution vary both with the duration of the hepatitis and the degree of icterus. In severely jaundiced cases studied during the first week following onset, the level of total plasma cholesterol is appreciably reduced, the concentration of phospholipids is not proportionately reduced, with the result that there is a marked lowering in the cholesterolphospholipid ratio both in the plasma and in Fraction I + III. In these cases there is also a marked reduction in esterified cholesterol, with increase in the ratio of plasma free to total cholesterol. This is usually apparent also in Fraction I + III but is most marked in Fraction IV $+\mathrm{V}+\mathrm{VI}$, where almost none of the cholesterol is esterified (Table VI). In patients whose total cholesterol is less than normal, the percentage in Fraction $\mathrm{IV}+\mathrm{V}+\mathrm{VI}$ tends to be low. In the occasional patient with high concentration of total cholesterol there is an increase in the cholesterol in Fraction $\mathrm{IV}+\mathrm{V}+\mathrm{VI}$ such as is seen in biliary cirrhosis.

These striking deviations in concentration and distribution of lipids tend to disappear gradually with recovery from the disease and particularly with the subsidence of icterus. They may disappear entirely before clinical convalescence is complete. Among the nineteen cases whose study was begun more than a week after the onset, there were seven whose bilirubin concentration was less than $2 \mathrm{mg}$. per $100 \mathrm{ml}$. In these cases, low cholesterol-phospholipid ratios in the plasma and in Fraction I + III were not found. In patients fol- 
PROTEIN-LIPID RELATIONSHIPS IN HUMAN PLASMA

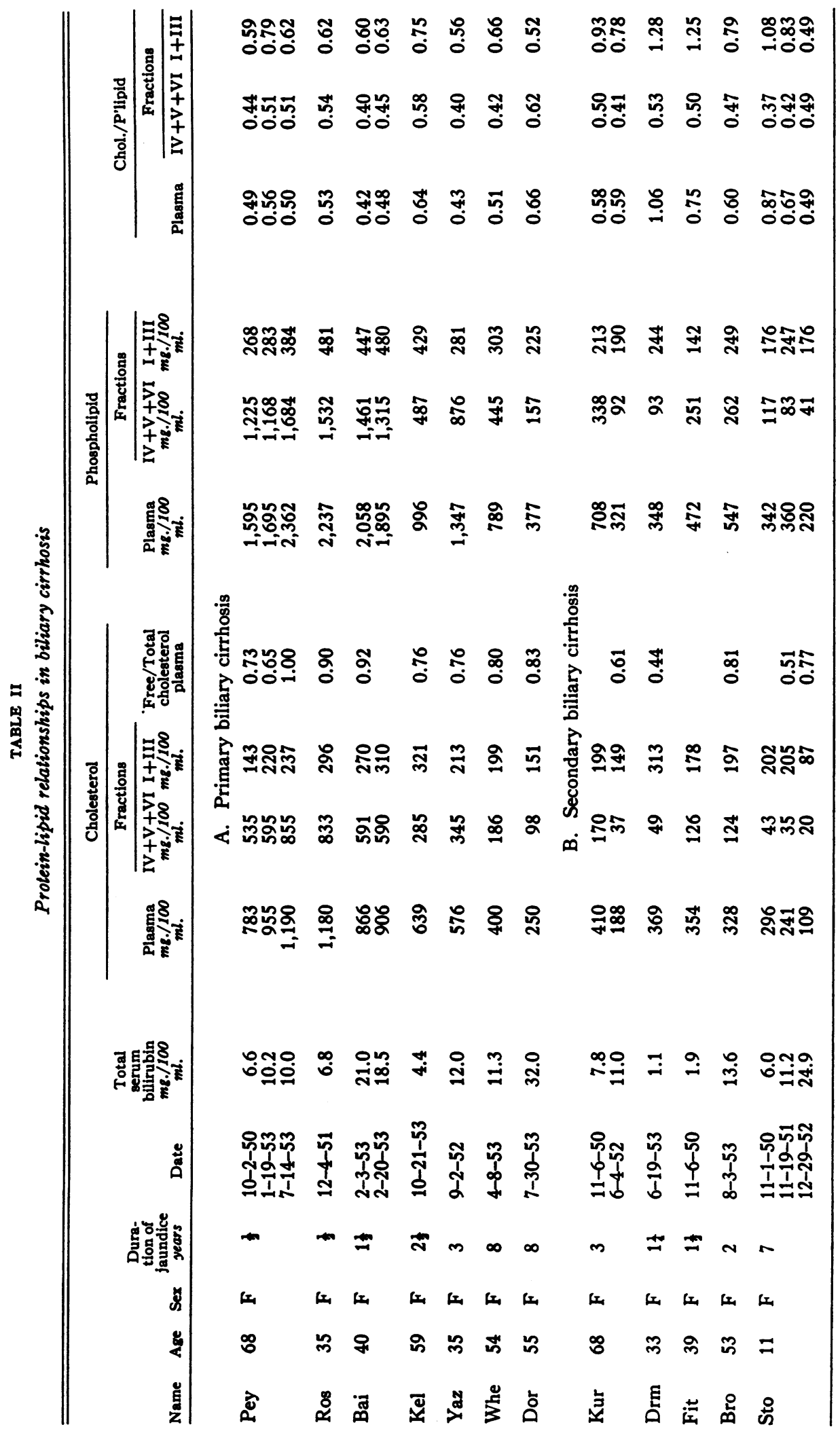




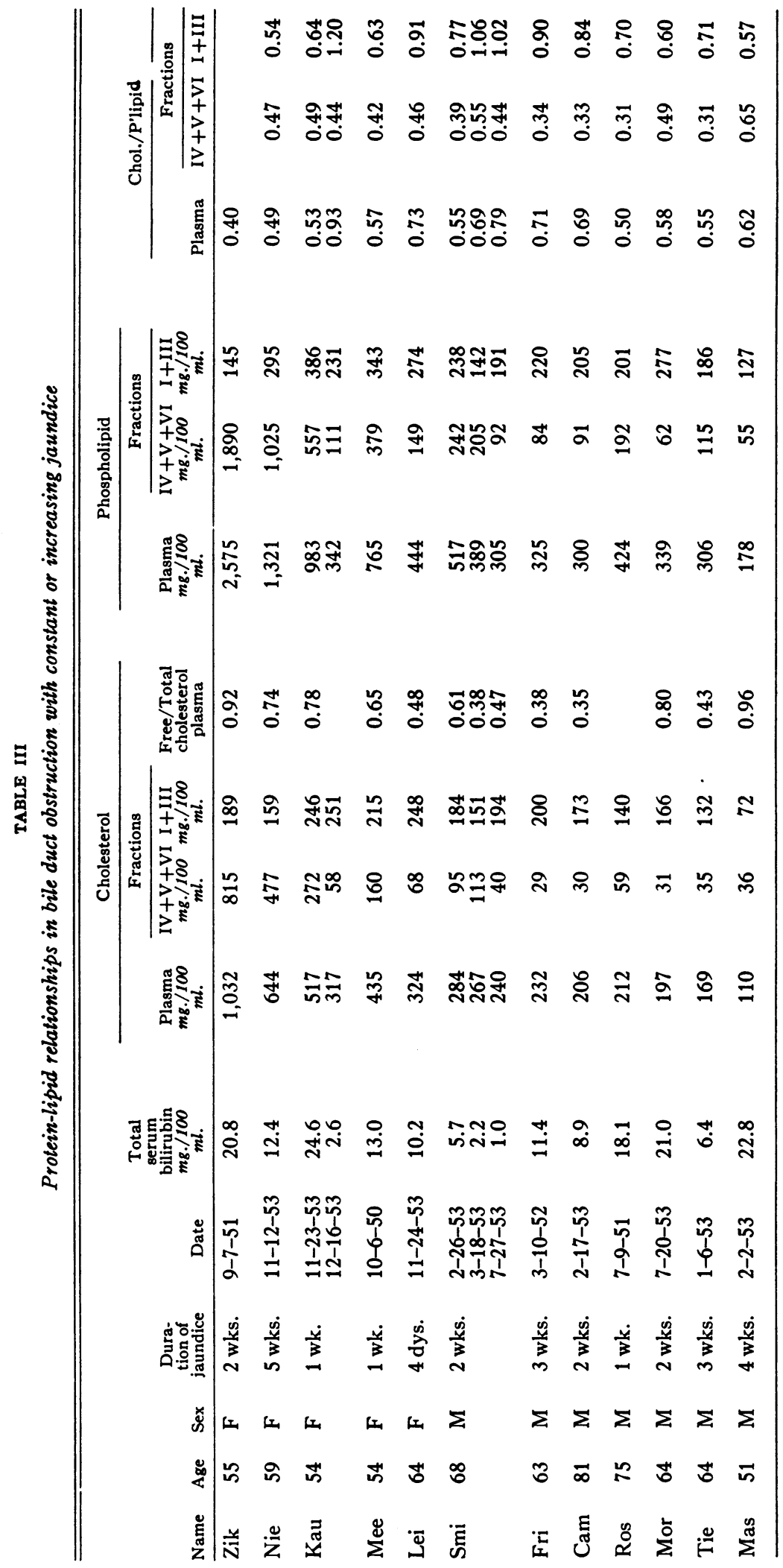




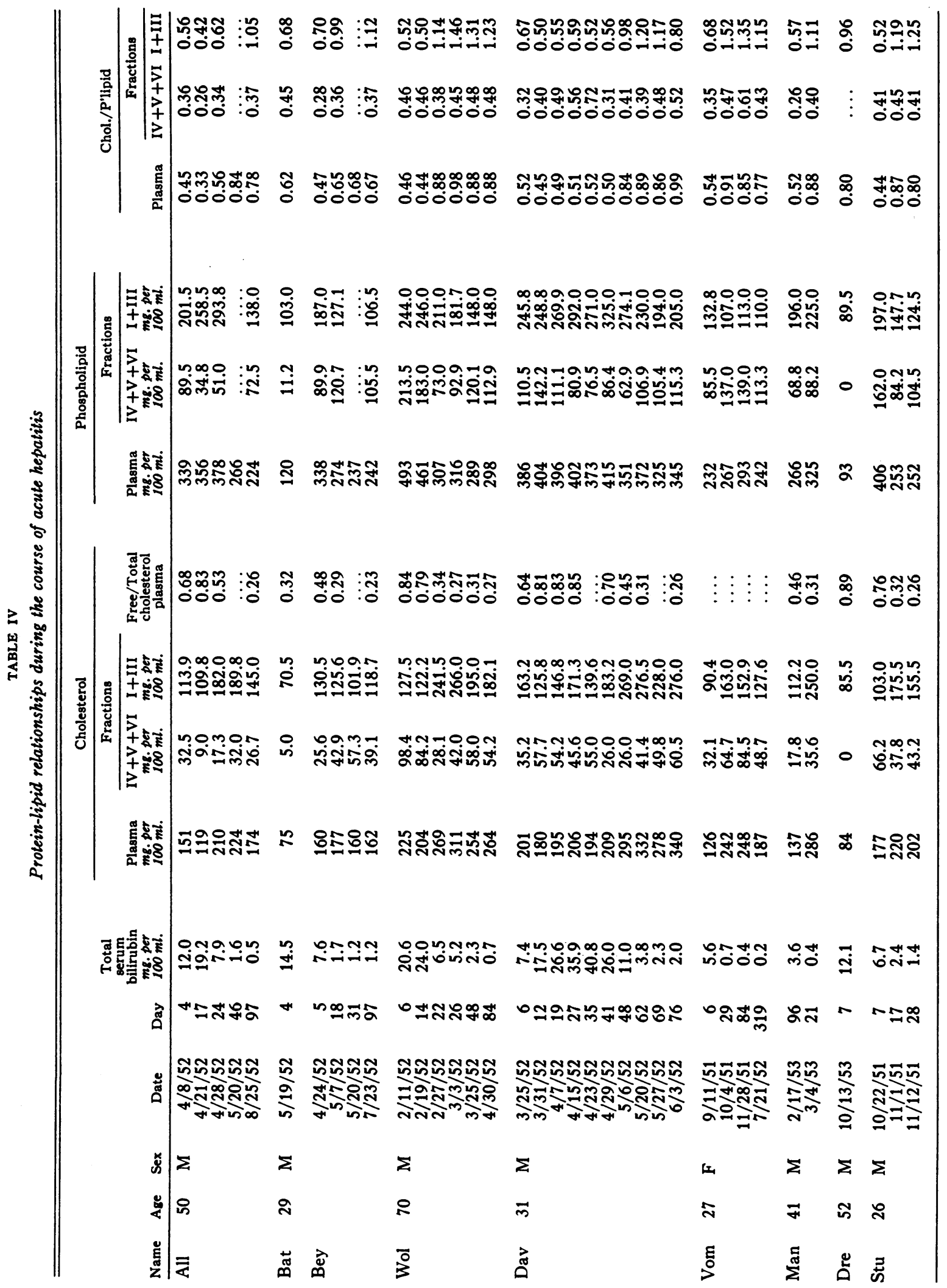




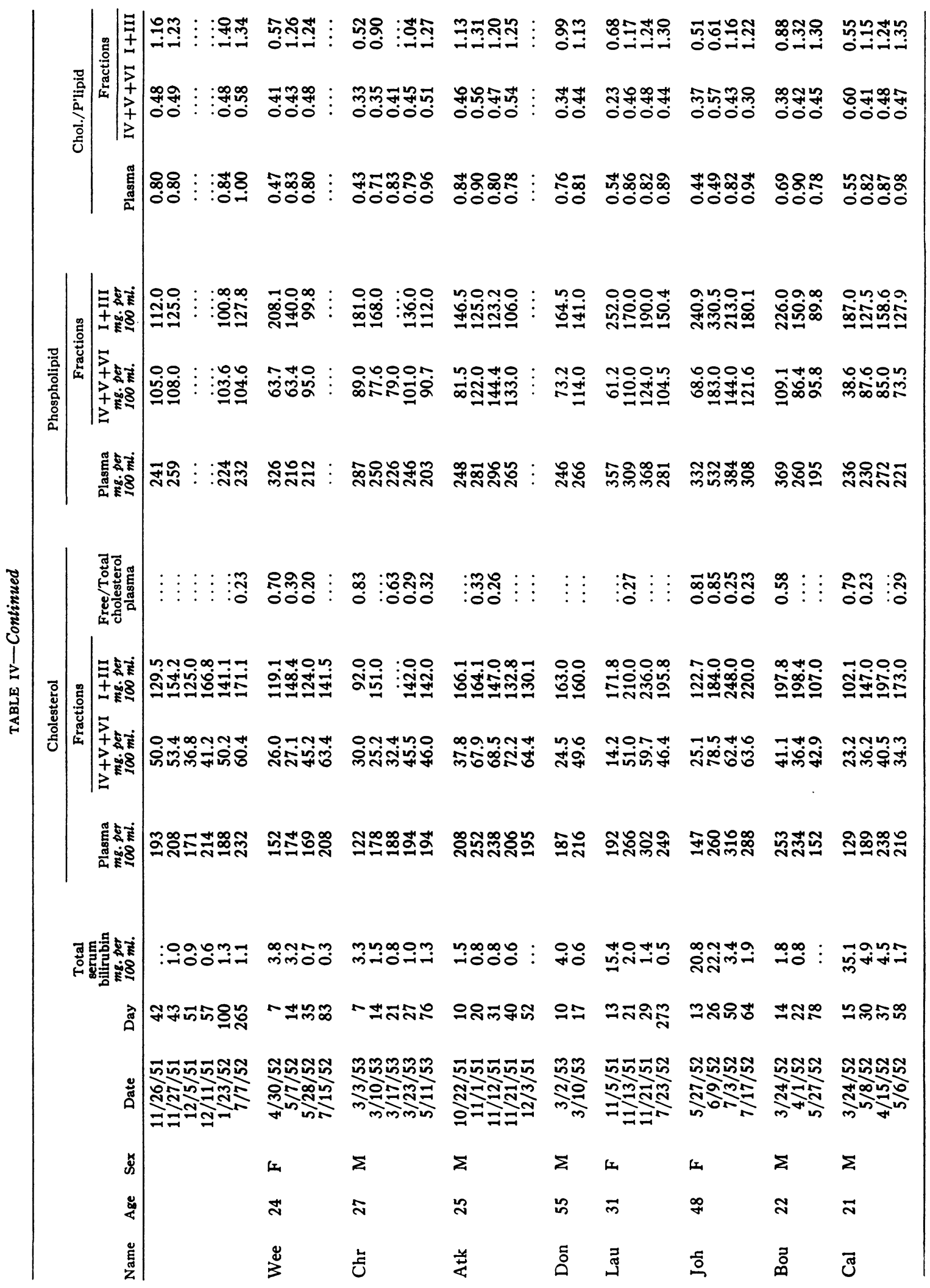




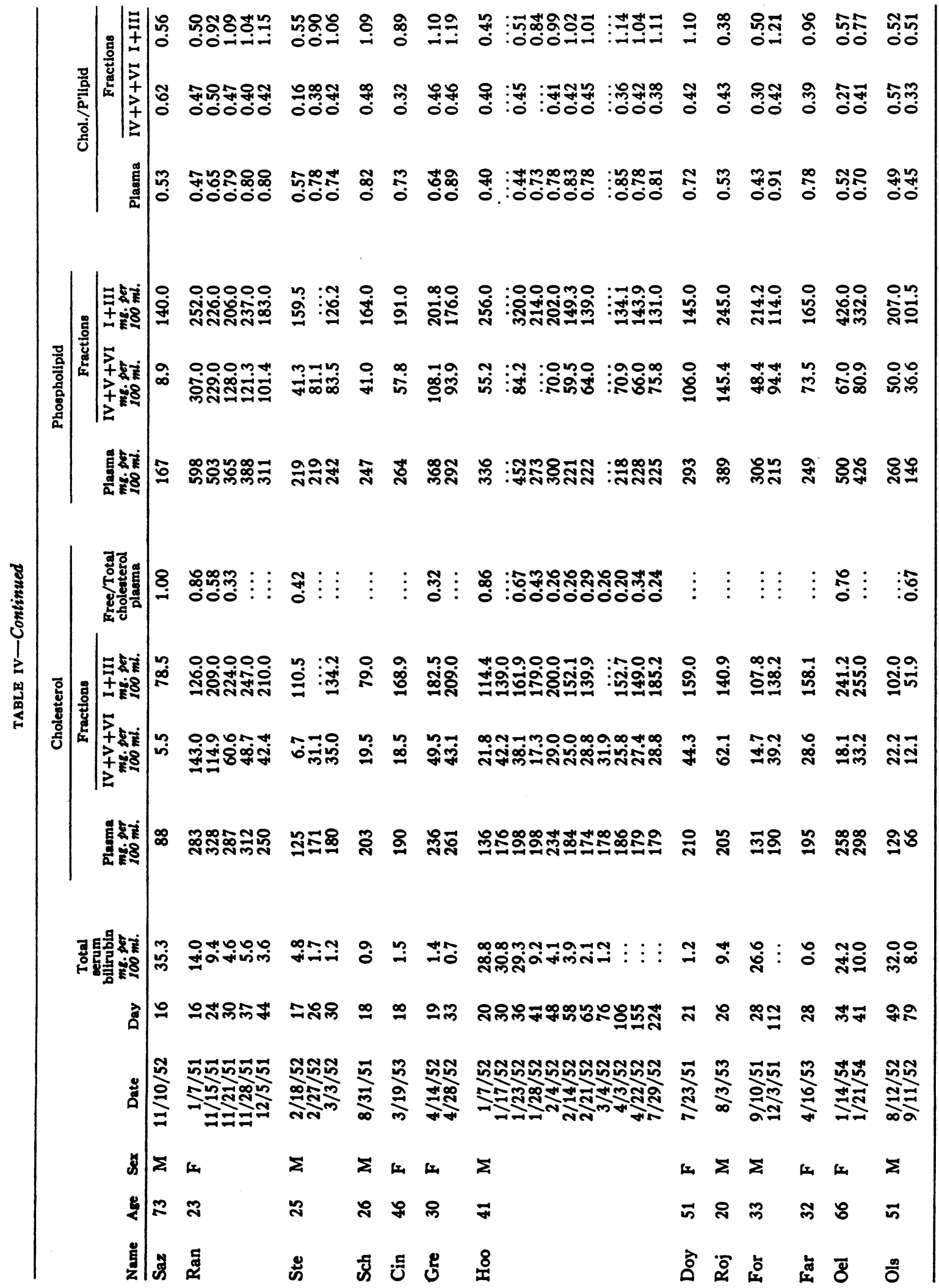




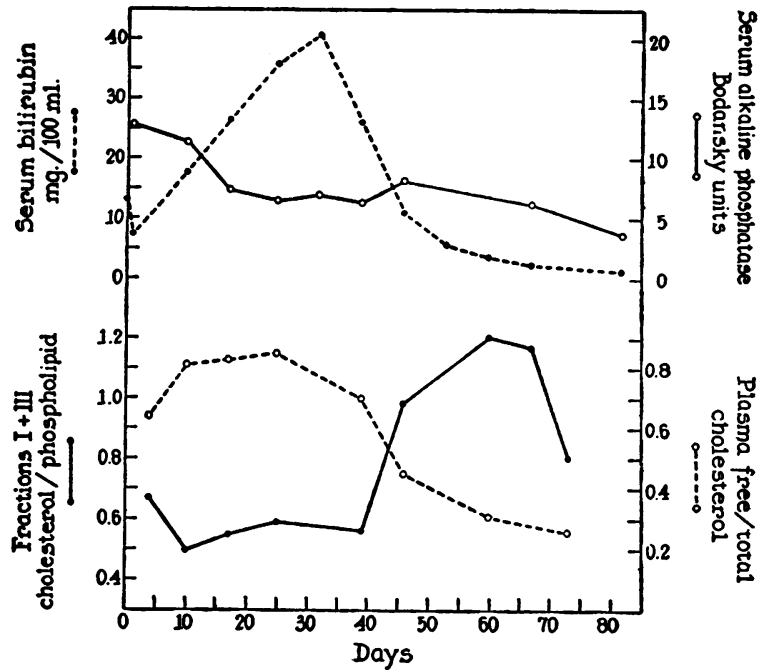

Fig. 1. Relationship of Several Chemical Tests During the Course of a Typical Case of Hepatitis

lowed serially from the acute phase through recovery, the cholesterol-phospholipid ratio in the plasma and in Fraction I + III was observed to rise simultaneously with the fall in serum bilirubin concentration and the ratio of free to total cholesterol. The return to normal in cholesterol and phospholipid relationships appears to be related to recovery and to the decrease in serum bilirubin concentration. It seems to be independent of the initial bilirubin concentration. In Dav the pattern returns to normal when the bilirubin concentration decreases from 26 to $11 \mathrm{mg}$. per $100 \mathrm{ml}$, while in Man this happens when the bilirubin falls from 3.6 to $0.4 \mathrm{mg}$. per $100 \mathrm{ml}$.

Usually the serum alkaline phosphatase concentration decreases with the bilirubin, but the correlation between the phosphatase and the lipid pattern is far from exact. No correlation can be established for the change in pattern and the changes in bromsulfalein excretion or cephalin flocculation or thymol turbidity tests. Our data are not sufficient to establish presence or absence of correlation between the lipid pattern and the urinary excretion of bile and urobilinogen. In Figure 1 are shown the patterns of change in a typical case of acute hepatitis.

\section{Portal cirrhosis}

In Table $\mathrm{V}$ are shown the data in patients with portal cirrhosis who have been listed in order of descending plasma cholesterol concentration. Listed separately are one case of hemochromatosis and five adolescent females, with the syndrome described by Bongiovanni and Eisenmenger (11) and characterized by high content of protein (up to $5.99 \mathrm{gm}$. per $100 \mathrm{ml}$. in Mar) in Fraction II.

The lipid deviations in this group are extremely variable. The total cholesterol concentration varies between the wide limits of 551 and $44 \mathrm{mg}$. per $100 \mathrm{ml}$. In twenty of the thirty-six patients the plasma cholesterol is less than the lower limit of normal and in four patients cholesterol values of less than $100 \mathrm{mg}$. per $100 \mathrm{ml}$. are observed. Generally, there is a decrease in cholesterol in Fraction IV $+\mathrm{V}+\mathrm{VI}$ while that in Fraction I + III varies, depending upon the total plasma concentration. In the majority of cases the phospholipid varies with cholesterol as in normal subjects so that the ratios of cholesterol to phospholipid are not different from normal, but in nine of the patients low cholesterol-phospholipid ratios in the plasma and Fraction I + III are observed. In five of them free to total cholesterol ratios in the plasma are measured, and in four they are over 0.75 . Two other patients have ratios over 0.70 : in Alt the cholesterol-phospholipid ratios are normal, but in Ede they are low but not as low as in the patients discussed. In the other patients with portal cirrhosis the mean ratio of the free to total cholesterol is 0.50 . In these patients with the abnormal lipid pattern serum bilirubin is usually elevated. Although Rob, Bur, and Car were in the terminal phase of their disease, the other patients were not regarded as having an immediately grave prognosis. In Guz and Rob the transient nature of these episodes is shown. With the disappearance of the intense jaundice the cholesterol-phospholipid and free to total cholesterol ratios return to levels seen in the remainder of the patients with cirrhosis.

In the cases of Table VI in which the SperrySchoenheimer determinations were carried out on the fractions of plasma, the observations are not sufficient in number to permit any general statement. It will be noted, however, that in biliary cirrhosis and in the acute stage of the acute hepatitis the cholesterol content of Fraction IV $+\mathrm{V}+$ VI is almost entirely unesterified, while in Fraction I + III some of the cholesterol is esterified. 


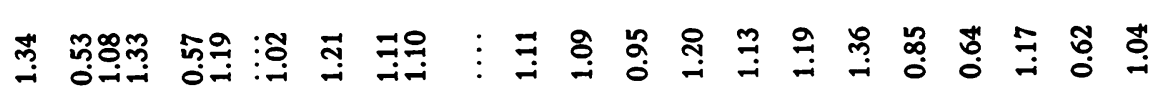

華

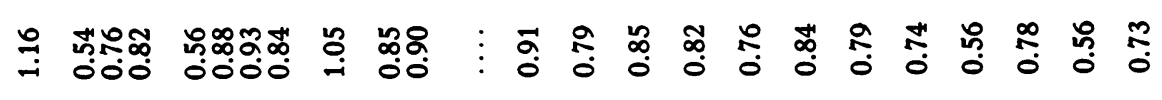

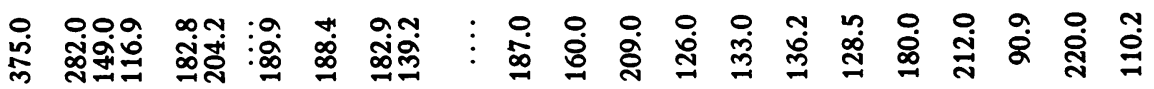

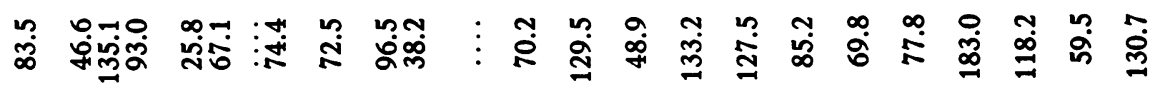

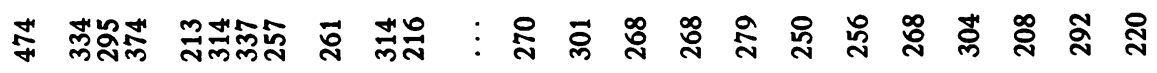

苟

究 5 ע้

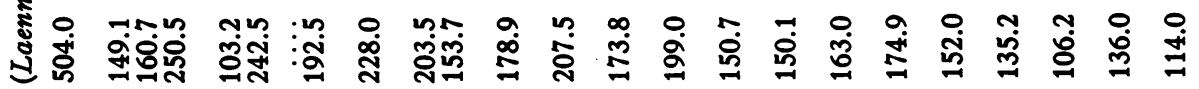
जี

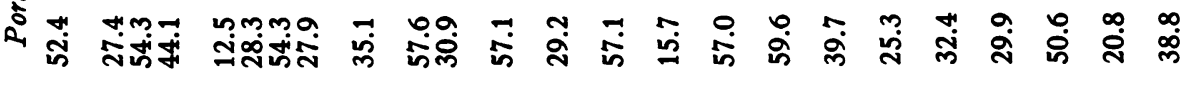

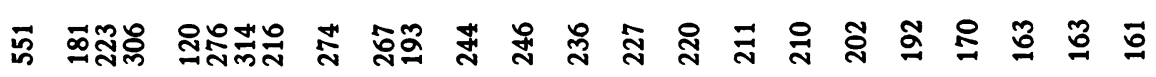

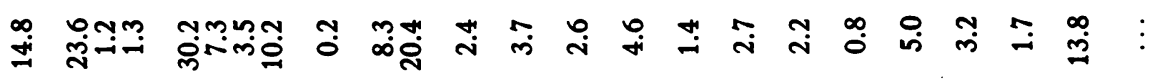

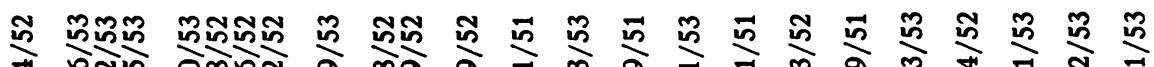
方 
TABLE VI

Free cholesterol, esterified cholesterol, and free to total cholesterol ratios in Fractions $I V+V+V I$ and $I+I I I$

\begin{tabular}{|c|c|c|c|c|c|c|c|c|c|c|}
\hline \multirow[b]{3}{*}{ Name } & \multirow[b]{3}{*}{ Date } & \multirow{2}{*}{\multicolumn{3}{|c|}{ Plasma }} & \multicolumn{6}{|c|}{ Cholesterol } \\
\hline & & & & & \multicolumn{3}{|c|}{ Fraction IV +V +VI } & \multicolumn{3}{|c|}{ Fraction I+III } \\
\hline & & $\begin{array}{c}\text { Ester } \\
m g . \text { per } \\
100 \mathrm{ml} .\end{array}$ & $\begin{array}{c}\text { Free } \\
m g . ~ p e r \\
100 \mathrm{ml} .\end{array}$ & $\begin{array}{l}\text { Free/ } \\
\text { Total }\end{array}$ & $\begin{array}{c}\text { Ester } \\
m g . \text { per } \\
100 \mathrm{ml} .\end{array}$ & $\begin{array}{c}\text { Free } \\
m g . p e r \\
100 \mathrm{ml} .\end{array}$ & $\begin{array}{l}\text { Free/ } \\
\text { Total }\end{array}$ & $\begin{array}{c}\text { Ester } \\
m g . \text { per } \\
100 \mathrm{ml} .\end{array}$ & $\begin{array}{c}\text { Free } \\
\text { mg. per } \\
100 \mathrm{ml} .\end{array}$ & $\begin{array}{l}\text { Free/ } \\
\text { Total }\end{array}$ \\
\hline \multicolumn{11}{|c|}{ Primary biliary cirrhosis } \\
\hline $\begin{array}{l}\text { Ros } \\
\text { Yaz } \\
\text { Whe }\end{array}$ & $\begin{array}{r}12 / 21 / 51 \\
9 / 2 / 52 \\
4 / 8 / 53\end{array}$ & $\begin{array}{r}17.0 \\
157.0 \\
96.0\end{array}$ & $\begin{array}{r}1,023.0 \\
509.0 \\
390.0\end{array}$ & $\begin{array}{l}0.90 \\
0.76 \\
0.80\end{array}$ & $\begin{array}{c}15.0 \\
0 \\
4.0\end{array}$ & $\begin{array}{l}816.0 \\
410.0 \\
230.0\end{array}$ & $\begin{array}{l}0.98 \\
1.00 \\
0.98\end{array}$ & $\begin{array}{r}115.0 \\
106.0 \\
87.0\end{array}$ & $\begin{array}{l}167.0 \\
113.0 \\
109.0\end{array}$ & $\begin{array}{l}0.89 \\
0.52 \\
0.56\end{array}$ \\
\hline \multicolumn{11}{|c|}{ Secondary biliary cirrhosis } \\
\hline Sto & $11 / 19 / 51$ & 108.0 & 110.0 & 0.51 & 4.5 & 24.1 & 0.84 & 85.0 & 86.0 & 0.50 \\
\hline \multicolumn{11}{|c|}{ Bile duct obstruction } \\
\hline $\begin{array}{l}\mathrm{Zik} \\
\mathrm{Smi}\end{array}$ & $\begin{array}{r}9 / 7 / 51 \\
3 / 18 / 53\end{array}$ & $\begin{array}{r}96.0 \\
145.5\end{array}$ & $\begin{array}{r}1,095.0 \\
90.5\end{array}$ & $\begin{array}{l}0.92 \\
0.38\end{array}$ & $\begin{array}{l}17.0 \\
54.7\end{array}$ & $\begin{array}{r}860.0 \\
41.7\end{array}$ & $\begin{array}{l}0.98 \\
0.43\end{array}$ & $\begin{array}{l}83.0 \\
76.8\end{array}$ & $\begin{array}{r}148.0 \\
47.7\end{array}$ & $\begin{array}{l}0.64 \\
0.38\end{array}$ \\
\hline \multicolumn{11}{|c|}{ Acute hepatitis } \\
\hline $\begin{array}{l}\text { Lau } \\
\text { Saz } \\
\text { Ran } \\
\text { Hoo }\end{array}$ & $\begin{array}{r}3 / 31 / 52 \\
4 / 15 / 52 \\
10 / 22 / 51 \\
11 / 1 / 51 \\
11 / 12 / 51 \\
11 / 12 / 51 \\
1 / 10 / 52 \\
11 / 7 / 51 \\
11 / 15 / 51 \\
1 / 7 / 52 \\
1 / 23 / 52 \\
7 / 9 / 52 \\
9 / 11 / 52\end{array}$ & $\begin{array}{r}37.0 \\
25.0 \\
42.5 \\
129.5 \\
154.0 \\
179.3 \\
0 \\
40.0 \\
138.0 \\
17.0 \\
60.0 \\
117.4 \\
21.7\end{array}$ & $\begin{array}{r}161.0 \\
143.0 \\
134.5 \\
61.5 \\
54.0 \\
66.7 \\
63.2 \\
244.0 \\
193.0 \\
104.0 \\
124.0 \\
37.2 \\
44.6\end{array}$ & $\begin{array}{l}0.81 \\
0.85 \\
0.76 \\
0.32 \\
0.26 \\
0.27 \\
1.00 \\
0.86 \\
0.58 \\
0.86 \\
0.67 \\
0.24 \\
0.67\end{array}$ & $\begin{array}{c}0 \\
0 \\
0 \\
20.8 \\
35.2 \\
27.6 \\
1.3 \\
0 \\
1.2 \\
0 \\
3.6 \\
29.1 \\
5.0\end{array}$ & $\begin{array}{r}51.3 \\
27.6 \\
64.6 \\
7.0 \\
8.8 \\
8.4 \\
0.7 \\
141.0 \\
94.0 \\
15.0 \\
27.0 \\
5.2 \\
5.0\end{array}$ & $\begin{array}{l}1.00 \\
1.00 \\
1.00 \\
0.25 \\
0.20 \\
0.23 \\
. \ldots 0 \\
1.00 \\
0.89 \\
1.00 \\
0.88 \\
0.15 \\
0.50\end{array}$ & $\begin{array}{r}131.0 \\
41.4 \\
43.2 \\
100.6 \\
102.4 \\
136.7 \\
7.5 \\
34.9 \\
91.4 \\
25.6 \\
42.0 \\
78.2 \\
27.1\end{array}$ & $\begin{array}{r}120.0 \\
101.1 \\
65.8 \\
45.4 \\
40.6 \\
57.3 \\
63.2 \\
94.1 \\
81.6 \\
82.4 \\
99.5 \\
37.8 \\
38.0\end{array}$ & $\begin{array}{l}0.92 \\
0.71 \\
0.60 \\
0.31 \\
0.28 \\
0.30 \\
0.88 \\
0.73 \\
0.47 \\
0.76 \\
0.70 \\
0.33 \\
0.58\end{array}$ \\
\hline \multicolumn{11}{|c|}{ Portal cirrhosis } \\
\hline $\begin{array}{l}\text { Rob } \\
\text { Gau } \\
\text { Pri } \\
\text { Lew } \\
\text { Hog } \\
\text { Piz }\end{array}$ & $\begin{array}{r}2 / 20 / 52 \\
5 / 6 / 52 \\
6 / 19 / 52 \\
6 / 1 / 53 \\
2 / 3 / 53 \\
6 / 2 / 53 \\
6 / 1 / 53\end{array}$ & $\begin{array}{r}28.5 \\
145.1 \\
165.4 \\
88.3 \\
77.1 \\
55.3 \\
58.8\end{array}$ & $\begin{array}{r}84.8 \\
106.6 \\
87.6 \\
89.2 \\
120.5 \\
53.3 \\
64.0\end{array}$ & $\begin{array}{l}0.75 \\
0.42 \\
0.35 \\
0.50 \\
0.61 \\
0.49 \\
0.52\end{array}$ & $\begin{array}{r}2.1 \\
21.3 \\
20.2 \\
24.4 \\
4.6 \\
24.3 \\
21.9\end{array}$ & $\begin{array}{r}9.7 \\
15.5 \\
6.2 \\
26.0 \\
26.9 \\
15.3 \\
17.0\end{array}$ & $\begin{array}{l}0.82 \\
0.42 \\
0.23 \\
0.52 \\
0.85 \\
0.39 \\
0.44\end{array}$ & $\begin{array}{r}25.0 \\
104.0 \\
127.7 \\
63.4 \\
78.3 \\
39.2 \\
40.6\end{array}$ & $\begin{array}{l}74.0 \\
62.9 \\
65.8 \\
61.5 \\
75.2 \\
33.2 \\
47.2\end{array}$ & $\begin{array}{l}0.75 \\
0.38 \\
0.34 \\
0.49 \\
0.48 \\
0.46 \\
0.54\end{array}$ \\
\hline
\end{tabular}

\section{Filter paper electrophoresis}

Normal plasma has two principal lipid-staining components; namely, an intense deeply-stained spot occurs in the beta globulin area and another, less intense, in the area between alpha ${ }_{1}$ globulin and albumin. In biliary cirrhosis, despite the high lipid content of the plasma, the alpha component is negligibly small and all of the stainable lipid appears to be present in the beta area. Similar patterns have been found in obstructive jaundice and acute hepatitis. With disappearance of icterus, stainable lipid then appears in the alpha area.

Fraction IV $+\mathrm{V}+\mathrm{VI}$ from the plasma of a patient with biliary cirrhosis was subjected to paper electrophoresis, and all the lipids were found to migrate with the mobility of beta globulin, and when run on a starch block the fraction had a large single lipid peak with a cholesterol-phospholipid ratio of 0.50 . The lipoprotein of Fraction I + III on filter paper also migrated to the beta area.

\section{Ultracentrifugal flotation}

In Table VII are shown comparisons of the separation made by ultracentrifugal flotation with those made by Cohn fractionation. In this table, the per cent of total cholesterol and phospholipid found in the bottom fraction (containing alpha lipoproteins) is compared with that found in Fraction IV $+\mathrm{V}+\mathrm{VI}$ which ordinarily contains alpha lipoproteins. In one normal subject and in two patients with hypercholesterolemic xanthomatosis the correlation between the two techniques 
is good. In Tad it was not quite so close. In three patients with biliary cirrhosis and in one with acute hepatitis there is much less lipid in the bottom fraction than in Fraction IV $+\mathrm{V}+\mathrm{VI}$. This correlates well with the comparable studies by filter paper electrophoresis.

\section{DISCUSSION}

In these patients with obstructive jaundice, the lipid composition of the lipoprotein-containing fractions differs markedly from that found in normal plasma and in the plasma from patients with atherosclerosis and related diseases. Furthermore, these lipoproteins have physical properties different from those ordinarily found. The lipoproteins in Fraction IV + V + VI as well as those in Fraction I + III have the electrophoretic mobility of beta globulins. The greater part of the lipoprotein in Fraction IV + V + VI has a density of less than 1.063 as does all the lipoprotein in Fraction I + III. The lipoproteins separated by the physical methods also differ in chemical composition from those usually found. Kunkel and Slater (9) have shown that the material migrating with the mobility of beta globulin on a starch block has a cholesterol-phospholipid ratio of 0.5 as contrasted to normal values of 1.26 for this peak. Similarly, the low density lipoproteins separated by ultracentrifugation have low cholesterol-phospholipid ratios.

At present, lipoproteins can be defined only by description of certain of their chemical and physical properties. On this basis it might be concluded that in obstructive jaundice there are $a b-$ normal lipoproteins in the plasma. It cannot be assumed, however, that these are newly synthesized compounds. Anfinsen (16) has pointed out that the abnormality might consist of an accumulation of lipoproteins which are normally present in only minute amounts. Another possibility is that the lipid-binding capacity of normal lipoproteins has been altered by unknown factors or as Byers, Friedman, Biggs, and Gunning (17) have suggested by accumulation of bile acids.

The evidence of the present study indicates that at least two types of these abnormal lipoproteins are present in patients with obstructive jaundice. One is soluble under the conditions of precipitation of Fraction I + III and therefore appears in Fraction $\mathrm{IV}+\mathrm{V}+\mathrm{VI}$, while the other is insoluble and is separated with Fraction I + III. Both have cholesterol-phospholipid ratios considerably lower than those normally found in Fraction I + III. They differ in their ratios of free to total cholesterol: the cholesterol in Fraction IV $+\mathrm{V}+$ VI is almost entirely free (unesterified) whereas in Fraction I + III the free cholesterol constitutes from 50 to 80 per cent of the total. Snavely, Goldwater, Randolph, and Unglaub (10) by ultracentrifugation of plasma from patients with acute hepatitis also obtained a fraction in which all the cholesterol was unesterified.

These abnormal lipoproteins are present in large amounts in biliary cirrhosis, and are often found in both intra- and extrahepatic obstruction of the biliary tract. They accumulate constantly in the early stages of the jaundice of acute hepatitis when intrahepatic obstruction of finer biliary radicals may be a feature (18). They have also been found in cerain patients in whom jaundice is

TABLE VII

Comparison of ultracentrifuge fractions with Cohn fractions

\begin{tabular}{|c|c|c|c|c|c|}
\hline \multirow[b]{2}{*}{ Name } & \multirow[b]{2}{*}{ Diagnosis } & \multicolumn{2}{|c|}{ Per cent of total cholesterol } & \multicolumn{2}{|c|}{ Per cent of total phospholipid } \\
\hline & & $\begin{array}{c}\text { Bottom } \\
\text { fraction }\end{array}$ & $\begin{array}{c}\text { Fraction } \\
\mathrm{IV}+\mathrm{V}+\mathrm{VI}\end{array}$ & $\begin{array}{c}\text { Bottom } \\
\text { fraction }\end{array}$ & $\begin{array}{c}\text { Fraction } \\
\text { IV +V+VI }\end{array}$ \\
\hline Wil & Normal female & 48.6 & 62.2 & 78.5 & 76.1 \\
\hline $\begin{array}{l}\text { Mis } \\
\text { Hid } \\
\text { Tad }\end{array}$ & $\begin{array}{l}\text { Hypercholesterolemic xanthomatosis } \\
\text { Hypercholesterolemic xanthomatosis } \\
\text { Hypercholesterolemic xanthomatosis }\end{array}$ & $\begin{array}{l}7.4 \\
.7 .6 \\
6.8\end{array}$ & $\begin{array}{r}6.4 \\
10.4 \\
3.2\end{array}$ & $\begin{array}{l}24.1 \\
31.6 \\
15.0\end{array}$ & $\begin{array}{r}16.0 \\
26.1 \\
8.7\end{array}$ \\
\hline $\begin{array}{l}\text { Pey } \\
\text { Dor } \\
\text { Bro }\end{array}$ & $\begin{array}{l}\text { Biliary cirrhosis } \\
\text { Biliary cirrhosis } \\
\text { Biliary cirrhosis }\end{array}$ & $\begin{array}{r}3.4 \\
10.8 \\
7.0\end{array}$ & $\begin{array}{l}85.2 \\
39.2 \\
38.6\end{array}$ & $\begin{array}{r}5.0 \\
14.9 \\
14.4\end{array}$ & $\begin{array}{l}81.5 \\
41.1 \\
51.3\end{array}$ \\
\hline Roj & Acute hepatitis & 5.1 & 30.6 & 15.7 & 15.7 \\
\hline
\end{tabular}


marked and biliary obstruction apparently present. In two of the cases in this series (Alt and Sko) intense jaundice developed without accumulation of abnormal lipoproteins. In one of them (Sko) the jaundice may have been hemolytic rather than obstructive. In the other, no explanation is offered for the lack of correlation. In patients whose portal cirrhosis is associated with only moderate degrees of jaundice, these lipoproteins are not found.

It appears that the concentration of these abnormal lipoproteins is related to the liver's synthetic capacity. Thus, in patients with early biliary cirrhosis in whom liver function is relatively unimpaired, high plasma concentrations of these lipoproteins are found. As the disease progresses and liver function is impaired, the concentrations fall. In hepatitis, where hepatic function is of course impaired, high levels of abnormal lipoproteins are not found. Data from electrophoretic and ultracentrifugal separations indicate that when the abnormal lipoproteins accumulate there is certainly depression of the alpha lipoprotein concentration and probably also of the normal beta lipoprotein concentration. In recovery from acute hepatitis the return of the normal lipoproteins is indicated by a return of the lipid in Fraction IV + V + VI to normal concentrations and by elevation of the cholesterol-phospholipid ratio in Fraction I + III.

Accumulation of lipoproteins of altered chemical composition offers an explanation of some of the deviations in plasma-lipid relationships of liver disease that are common to our own data and those of Man, Kartin, Durlacher, and Peters (3) and of Albrink, Man, and Peters (5). In all the observations there is a correlation between low plasma cholesterol-phospholipid ratios and high plasma ratios of free to total cholesterol. It is evident that if most of the plasma lipoproteins have low cholesterol-phospholipid ratios, the plasma itself will also have a low ratio. Since little of the cholesterol in these lipoproteins is esterified, the plasma free to total cholesterol ratio will be elevated. Albrink, Man, and Peters (5) noted that "the ratio of free to total cholesterol is rarely as abnormal in cirrhosis with little or no icterus as it is in obstructive jaundice, although the liver damage may be far greater." This is consistent with the concept that these high free to total ratios are a consequence of the production of abnormal lipoproteins rather than an indication of parenchymal liver damage as had been earlier suggested (19).

The alterations in plasma lipids encountered in obstructive jaundice in man can be reproduced to some extent in animals by ligation of the common bile duct. In rats, Chanutin and Ludewig (20) demonstrated increases in serum free cholesterol with no increase in ester cholesterol and an increase in phospholipid proportional to the increase in free cholesterol. Byers, Friedman, and Michaelis (21) found similar changes in cholesterol. They showed (22) that hepatectomy prevented the rise in cholesterol and that (23) the amount of cholesterol that accumulated in the plasma was greater than could be explained by failure of biliary excretion. Subsequently, Fredrickson, Loud, Hinkelman, Schneider, and Frantz (24) showed that this increase in serum cholesterol following bile ligation is accompanied by a significant increase in the rate of cholesterol synthesis by the liver. It may be that the abnormal lipoproteins present in this circumstance may alter the partition of cholesterol between liver and plasma, and that this partition may control the rate of cholesterol synthesis.

\section{SUMMARY}

In obstructive jaundice and in early acute hepatitis the lipid composition of the lipid-containing protein fractions is markedly deviant from that of normals and of all other diseases we have studied.

In Fraction IV $+\mathrm{V}+\mathrm{VI}$ there is approximately twice as much phospholipid as cholesterol, just as is found normally in that fraction. However, almost all of the cholesterol in the fraction is unesterified. The lipoproteins in this fraction have the electrophoretic and ultracentrifugal properties of beta lipoproteins, whereas normally they are high-density alpha lipoproteins.

The lipoproteins in Fraction I + III, like those normally in this fraction, have the physical characteristics of beta lipoproteins. Their proportion of ester cholesterol is less than normal. The most striking difference from normal lies in their cholesterol-phospholipid ratios which may be as low as 0.5 by weight. 
It is concluded that in biliary cirrhosis, in some cases of obstructive jaundice, and in early acute hepatitis there are at least two types of abnormal lipoproteins, the one found in Fraction IV $+\mathrm{V}+$ VI and the other in Fraction I + III.

During the recovery phase of acute hepatitis and following the removal of biliary tract obstruction, the abnormal lipoproteins are replaced by lipoproteins of normal composition.

The lack of correlation between the appearance of these lipoproteins and the degree of hepatic damage in cases of portal cirrhosis indicates that factors other than injury to the liver are implicated in their formation.

\section{REFERENCES}

1. Flint, A., Jr., Experimental researches into a new excretory function of the liver; consisting in the removal of cholesterine from the blood, and its discharge from the body in the form of stercorine. Am. J. M. Sc., 1862, n.s. 44, 305.

2. Widal, F., Weill, A., and Laudat, M., La lipémie des brightiques; rapports de la rétinite des brightiques avec lazotemie et la cholésterinémie. Semana méd., 1912, 32, 529.

3. Man, E. B., Kartin, B. L., Durlacher, S. H., and Peters, J. P., The lipids of serum and liver in patients with hepatic diseases. J. Clin. Invest., 1945, 24, 623.

4. Ahrens, E. H., Jr., and Kunkel, H. G., The relationship between serum lipids and skin xanthomata in eighteen patients with primary biliary cirrhosis. J. Clin. Invest., 1949, 28, 1565.

5. Albrink, M. J., Man, E. B., and Peters, J. P., Serum lipids in infectious hepatitis and obstructive jaundice. J. Clin. Invest., 1950, 29, 781.

6. Pierce, F. T., and Gofman, J. W., Lipoproteins, liver disease, and atherosclerosis. Circulation, 1951, 4, 25.

7. Pierce, F. T., Jr., Kimmel, J. R., and Burns, T. W., Lipoproteins in infectious and serum hepatitis. Metabolism, 1954, 3, 228.

8. McGinley, J., Jones, H., and Gofman, J., Lipoproteins and xanthomatous diseases. J. Invest. Dermat., 1952, 19, 71.

9. Kunkel, H. G., and Slater, R. J., Lipoprotein patterns of serum obtained by zone electrophoresis. J. Clin. Invest., 1952, 31, 677.

10. Snavely, J. R., Goldwater, W. H., Randolph, M. L., and Unglaub, W. G., The lipid composition of ultracentrifugates of serum from patients with acute hepatitis. J. Clin. Invest., 1952, 31, 664.
11. Bongiovanni, A. M., and Eisenmenger, W. J., Adrenal cortical metabolism in chronic liver disease. J. Clin. Endocrinol., 1951, 11, 152.

12. Russ, E. M., Eder, H. A., and Barr, D. P., Proteinlipid relationships in human plasma. I. In normal individuals. Am. J. Med., 1951, 11, 468.

13. Sperry, W. M., and Webb, M., A revision of the Schoenheimer-Sperry method for cholesterol determination. J. Biol. Chem., 1950, 187, 97.

14. Russ, E. M., Eder, H. A., and Barr, D. P., Proteinlipid relationships in human plasma. III. In pregnancy and the newborn. J. Clin. Invest., 1954, 33, 1662 .

15. Boyle, E., Personal communication.

16. Anfinsen, C. B., Symposium on Atherosclerosis, Irving Page, ed., National Research Council, Washington, D. C., 1955, Publ. No. 338, 249 p.

17. Byers, S. O., Friedman, M., Biggs, M. W., and Gunning, B., Observations concerning the production and excretion of cholesterol in mammals. IX. The mechanism of the hypercholesterolemic effect of cholic acid. J. Exper. Med., 1953, 97, 511.

18. Watson, C. J., and Hoffbauer, F. W., Liver function in hepatitis. Ann. Int. Med., 1947, 26, 813.

19. Thannhauser, S. J., and Schaber, H., Über die Beziehungen des Gleichgewichtes Cholesterin und Cholesterinester im Blut und Serum zur Leberfunktion. Klin. Wchnschr., 1926, 5, 252.

20. Chanutin, A., and Ludewig, S., The blood plasma cholesterol and phospholipid phosphorus in rats following partial hepatectomy and following ligation of the bile duct. J. Biol. Chem., 1936, 115, 1.

21. Byers, S. O., Friedman, M., and Michaelis, F., Observations concerning the production and excretion of cholesterol in mammals. I. Plasma cholesterol after bile duct ligation and free cholesterol injection. J. Biol. Chem., 1950, 184, 71.

22. Byers, S. O., Friedman, M., and Michaelis, F., Observations concerning the production and excretion of cholesterol in mammals. III. The source of excess plasma cholesterol after ligation of the bile duct. J. Biol. Chem., 1951, 188, 637.

23. Byers, S. O., and Friedman, M., Observations concerning the production and excretion of cholesterol in mammals. $\mathrm{V}$. The relation of biliary retention of cholesterol, distention of the biliary tract, the shunting of bile to the vena cava, and the removal of the gastro-intestinal tract to the hypercholesteremia consequent on biliary obstruction. J. Exper. Med., 1952, 95, 19.

24. Fredrickson, D. S., Loud, A. V.. Hinkelman, B. T.. Schneider, H. S., and Frantz, I. D., Jr., The effect of ligation of the common bile duct on cholesterol synthesis in the rat. J. Exper. Med., 1954, 99, 43. 